\title{
Management of the investment value of land plots during complex residential development
}

\author{
Kirill Kulakov ${ }^{1, *}$ \\ ${ }^{1}$ Moscow State University of Civil Engineering, 26, Yaroslavskoye Shosse, 129337, Moscow, Russia
}

\begin{abstract}
The article is dedicated to the analysis of the research object in the form of residential sphere related to preparation, implementation and state regulation of investment projects on complex residential development of territories at the stage of land development applying modeling and investment value management methodology. The rationale of the performed studies presented in the article is related to the necessity of development of methodological approaches to accurate modeling and management of the investment value at the stage of land development on preparation of land plots for constriction, which is the basis of efficient state regulation of investment attractiveness of the complex residential development through the methods of the public-private partnership. The article demonstrates both the proprietary methodology, and the received results in the form of scientific and practical results that allow to perform investment cost management of projects on complex residential development in order to leave the area of negative investment attractiveness. These management solutions are recommended on the basis of optimum parameters of the public-private partnership.
\end{abstract}

\section{Introduction}

Author's research has shown that the Russian theory of professional real estate development at the stage of land development pays insufficient consideration both to the aspects of the residential market development in the segment of complex residential development of the territory, and to the issues of management of the land plots investment value when implementing these types of projects.

Performed analysis confirmed that economic tools of accurate modeling and investment value management at the stage of land development on preparation of land plots for construction evidently function inefficiently. They do not account for the problems of modeling of optimum parameters of the public-private partnership of such investment projects depending on their financial efficiency with account for variables of number of floors, costs for compliance with technical specifications, level of the consolidated budget co-financing of social objects, as well as issues of their multivariant positioning in various territorial residential markets.

*Corresponding author: kkulakov@ciep.ru 
This situation shapes the problematic area for development of modeling and management of implementation of these investment projects and predetermines the necessity of state regulation of their attractiveness and liquidity through investment tools of the investment value of land plots for this type of complex residential development of territories. In this respect, we have defined and realized the research objective of development of methodological grounds and practical recommendations on modeling and management of the land plots investment value within complex development of territories for the purpose of residential construction based on the public-private partnership and territorial positioning.

\section{Literature review}

Performed analysis showed that in the international and Russian valuation practice the concept of investment value is widely used by developers to justify the decision and by other participants of investment activities participating in investment projects [1-14]. In the Russian Federation the notion of the investment value is regulated by Federal Law "On valuation activities in the Russian Federation" N 135-FZ of July 29, 1998 (as modified and amended), as well as by the Federal Valuation Standards. Apart from that, at the end of 2016 Federal Valuation Standard N 13 [1] was adopted concerning application of the investment value in the valuation practice.

Various methodological aspects of the investment value modeling and aspects of its management were discussed in publications of Russian scientists, such as: S. Baronin [2-7], S. Bazoev, I. Blank, G. Bulycheva, S. Gribovsky, S. Valdaytsev, A. Gryaznova, V. Grigoryev, E. Denisova [8], V. Kovalev, K. Kulakov [3,5,6,8], M. Rakovskaya [1,3] and others $[3,9,10]$. Russian and foreign scientists and specialists work on this topic, as the analysis showed $[7,9,11,12,14]$.

Literature review showed that scientific and practical sphere of application of the investment value in sphere of justification of investment projects on implementation of large projects of complex development of territories for the purpose of residential construction falls within especially complicated types of valuation activities and project management procedures. As a rule, the objective is to define the investment value required for the developer to make a decision about participation in a specific project, as well as for state and municipal governing authorities to determine investment attractiveness of initiated projects and plan the economic mechanism of the public-private partnership. Used methods of modeling and investment value management contain a number of issues that require their development since they do not account for the specifics of application in relation to especially complex residential development projects.

\section{Research methods}

Both recommendations of international valuation standards and Russian valuation standards were used as the main base of methodological modeling of the investment value. Pursuant to them, the investment value is the value of the valuated object for a specific investor or a group of investors for specific investment purposes.

In the Russian investment management practice in 2016 there was regulatory clarification of the investment value notion and methods of its estimation pursuant to federal valuation standard N 13 (FVS N 13) approved by decree of the Ministry of Economic Development of the RF N 722 of November 17, 2016. This methodology takes into account the amount of funds reflecting the useful effect from exploitation of the valuation object for a specific person or a group of persons (ability of the object to meet the needs of a specific person or a 
group of persons) pursuant to the investment purposes of exploitation of this valuation object set by this person(s).

The author performed methodological adjustment of the investment value notion that it is proposed to be viewed as a variety of the market value formed for a specific developer and investors focused on the implementation of the investment project of complex development of the territory, defining technical possibility, economic feasibility and efficiency of their participation in this type of residential construction based on the income approach and method of the proposed use pursuant to the land plot purchasing conditions at the auction, when the project's investment attractiveness is determined by the positive value of the net investment income as the indicator of useful effect.

Methodology implies calculation of the land plots' investment value and its modeling through criteria estimation of the investment value based on the indication of the net investment project income (NII). The author's methodological approach takes into consideration modeling of multivariant areas of land plots' investment attractiveness for complex development of territories pursuant to the main criteria of the NII.

The general picture of investment attractiveness of land plots shall be determined by presence of positive values of the investment value based on the indicators of the NII. It is possible to define various levels of investment attractiveness of land plots.

The modeling methodology stipulates two areas of investment attractiveness. First of all, this is positive investment attractiveness of those project types for investors with the positive values of the NII (Z1). At that, the model contemplates the zero area of attractiveness $(\mathrm{Y} 0)$, when $\mathrm{NII}=0$. This is the starting point of the investment interest with the minimum profitability equal to the discount rate. There are also additional areas $\mathrm{Z} 1$ with higher profitability $\mathrm{Y}+1, \mathrm{Y}+2, \mathrm{y}+3$, that are proposed to be formed with the $10 \%$ growth range from the zero NII value $(\mathrm{Y} 0)$.

Similarly it is proposed to model the negative area of the investment attractiveness (ZII) of complex residential development. In this case there are also three ranges $\mathrm{Y}-1, \mathrm{Y}-2, \mathrm{Y}-3$ demonstrating a various degree of attractiveness of land plots acqusition for complex residential development.

The targeted situational focus of land development for multivariant areas of land plots investment attractiveness may be aimed at the following types of investment projects: S1participation in the development of developed territories; S2 - participation in complex development of territories; S3- participation in the development of territories for the purpose of construction of the economy class residential objects; S4 - participation in complex development of territories for the purpose of construction of the economy class residential objects.

It is proposed to use the income approach as the basis of the methodological base for the investment value calculation. At that, from two options of the income method - capitalization method and cash flow discounting method - it is only possible to use the cash flow discounting method in the form of methodology of the proposed use of the land plot for complex residential development. The capitalization method is not used because the rental market for land plots of this type does not exist. It is possible to use the sales comparison approach if it is possible to compare the analyzed object with similar objects and to make necessary adjustments, although FVS13 does not stipulate application of the sales comparison approach [15].

Thus, it is proposed to use the method of proposed use of the land plot as the principal method to calculate its investment value, also, it is possible to use the sales comparison approach in certain cases. 


\section{Research results}

Use of results of the investment value modeling pursuant to the author's methodology using the example of the project "Bolshaya Sloboda" allowed to form a range of research results in the form of methodological recommendations on the investment value management for projects of complex residential development of territories in order to enter the positive area of investment attractiveness. It is recommended to implement these management decisions both based on the optimum parameters of the public-private partnership, and their multivariate positioning in various territorial residential markets.

At that, the process of management and optimization of its parameters implies procedures of modification of variables of the investment value in terms of the number of floors, share of the state and municipal budget participation in the costs for social real estate objects and their minimization, as well as the multivariate analysis of the project placement in the territorial markets.

With regard to the analyzed investment project, construction volumes of social real estate objects of around RUR $1600.00 \mathrm{mln}$ are taken as variables within the public-private partnership: schools (33.5\%); two kindergartens (25\%); a sports complex (33.5\%); marriage registration palace $(8 \%)$. Used options of the public-private partnership in terms of joint financing of the construction of social infrastructure objects and calculated values of the investment value in terms of the NII are specified in Table 1.

Table 1. Project's investment value modeling structure for 5 options of joint financing of social real estate objects in the project "Bolshaya Sloboda" within the public-private partnership.

\begin{tabular}{|c|c|c|c|}
\hline \multirow{2}{*}{ No. } & $\begin{array}{c}\text { Public-private partnership options } \\
\text { based on joint financing of } \\
\text { construction of social objects and } \\
\text { their engineering infrastructure }\end{array}$ & $\begin{array}{c}\text { Situation SI (nine 12- } \\
\text { story buildings, four 14- } \\
\text { story buildings) }\end{array}$ & $\begin{array}{c}\text { Situation (SII) - nine } \\
\text { 14-story buildings, } \\
\text { four 16-story } \\
\text { buildings }\end{array}$ \\
\cline { 3 - 4 } 1 & \multicolumn{2}{|c|}{$\begin{array}{c}\text { Project's investment value } \\
\text { based on the net investment income, mln RUR }\end{array}$} \\
\hline 1 & $\begin{array}{c}\text { Base option (0\% financed by the } \\
\text { state, 100\% financed by the } \\
\text { investor) }\end{array}$ & -195.038 & -69.699 \\
\hline 2 & $\begin{array}{c}\text { Option 1. (25\% financed by the } \\
\text { state, 75\% financed by the } \\
\text { investor) }\end{array}$ & 36.265 & 166.354 \\
\hline 3 & $\begin{array}{c}\text { Option 2. (50\% financed by the } \\
\text { state, 50\% financed by the } \\
\text { investor) }\end{array}$ & 268.67 & 402.599 \\
\hline 4 & $\begin{array}{c}\text { Option 3. (75\% financed by the } \\
\text { state, 25\% financed by the } \\
\text { investor) }\end{array}$ & 500.522 & 671.471 \\
\hline 5 & $\begin{array}{c}\text { Option 4. (99\% financed by the } \\
\text { state, 1\% financed by the investor) }\end{array}$ & 723.103 & 866.944 \\
\hline
\end{tabular}

An additional element of the investment value modeling is its optimization in terms of selection of the minimum possible value of the public-private partnership. This is proposed for implementation by graphic interpolation of received values of the investment value for various options of the public-private partnership. When these received 5 points are converted into linear trends for situations S1 and S2, then selection of minimum values of the publicprivate partnership is determined by the zero value of the investment value. These optimum variable values of the public-private partnership are $6.3 \%$ for option S2 and $18.75 \%$ for option S1. 
For these cases, land plots for this type of development shall be provided for free, and the level of their investment attractiveness should be recognized as the minimum allowed level. This is due to the fact that even in spite of the zero public-private partnership the developer has recurrent revenue costs with account for the discounting rate. It is recommended to use situation S2 with the level of the public-private partnership of $6.3 \%$ as the main calculation option to determine the project investment value assuring the minimum value of the consolidated budget of RUR $97.26 \mathrm{mln}$.

The final situation of the graphic and analytical modeling of the investment value is shown in Figure 1. These received results demonstrate both the process of forming and management of the project investment value in general, selection of the optimum value of the public-private partnership, and the residual investment value of the land plot (ISzy) from positive values of the NII for used multiplicators of $10 \%$ (Kmin ) and $30 \%(\mathrm{Kmax})$.

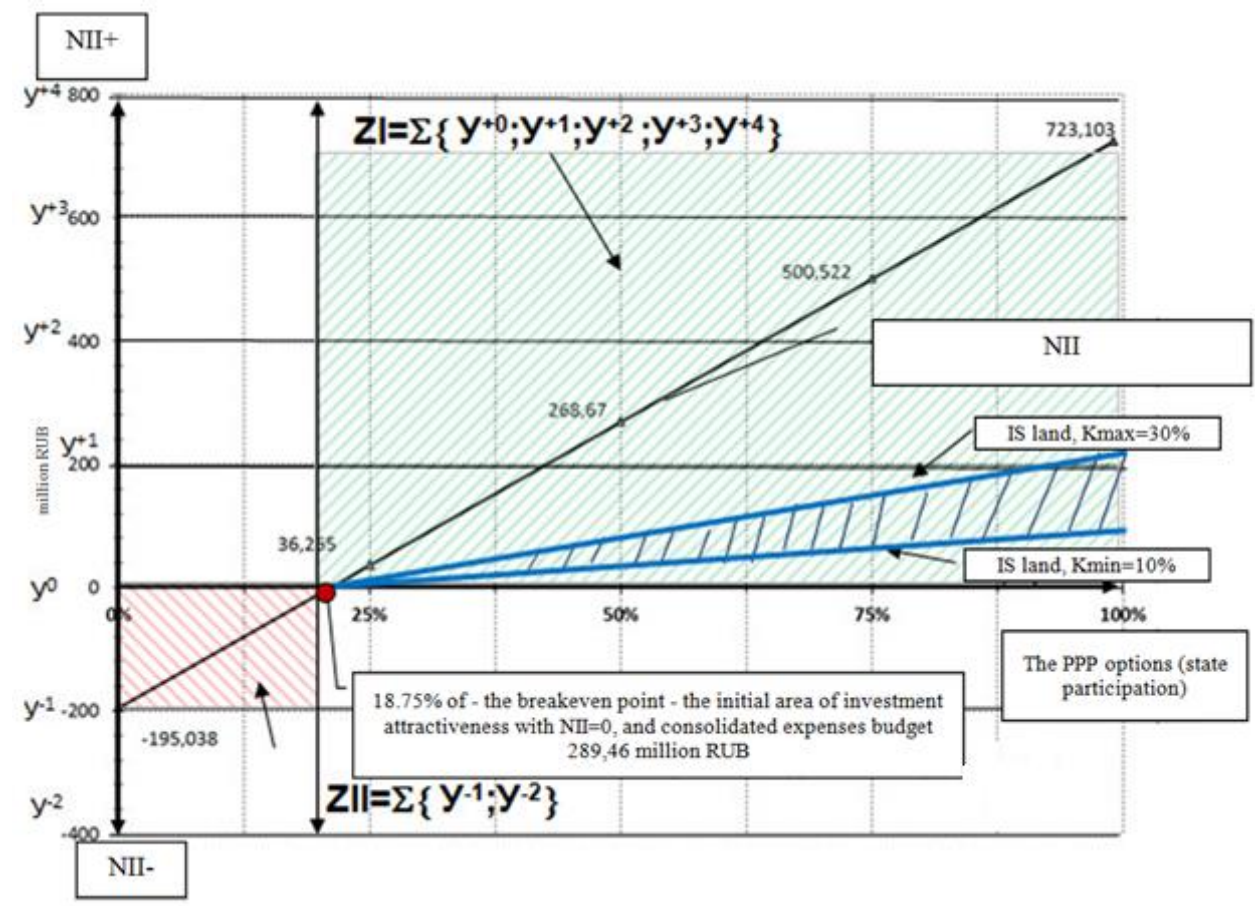

Fig.1. Multivariate modeling of zones of investment attractiveness of land plots for complex development of territories according to the criterion of the NII for the situation of S I with lowered floors.

Graphically, we have defined the acceptable financing level of social objects and their engineering infrastructure by the state in case of the public-private partnership. This point is located at the cross-section of the NII (disk) with the horizontal x-axis. Thus, the breakeven point (acceptable share of the state participation) was $18.75 \%$, which requires consolidated budget expenses in the amount of RUR $289.46 \mathrm{mln}$. In this point, NII = 0, which corresponds to the ZI zone.

\section{Discussion}

The polemical character of the research was confirmed by multiple cases of participation of the author with reports of the scientific and practical nature. Principal theoretical and practical 
points of the research results were reported at the seminars and conferences of the all-Russian and international levels, including Russian symposiums on valuation activities.

Theoretical and practical conclusions and recommendations of the research were put into practice in the activities of a number of Russian self-regulated organizations, in certain investment and development companies of Moscow and Moscow Region, in Center of Independent Expertise of Property LLC in Moscow, in the International Association of Residential Construction and Mortgaging Funds (MAIF) in Moscow, as well as in educational process of students of construction professions in the Moscow State University Of Civil Engineering (National Research University).

It is worth noting that the most important challenge of the research are formulated scientific and practical recommendations on the investment value management for land plots for complex residential development of the territory involving situational approach

with the negative investment value when the land plot does not appear attractive for the developer from the investment point of view. In this case it is recommended to adjust initial town-planning data and social load on the project to achieve positive values of NII

with the investment value of the project equal to zero, which is considered the starting point of the investment attractiveness of the land plot. At that, it is necessary to take the investment value of the land plot equal to zero

with the investment value of the project above zero when the land plot is attractive from the investment point of view with a different level of profitability.

Different volumes of commercial development in the course of development of the territory should be considered a quite promising direction of the investment value management, because this kind of development may bring additional profit to the developer and its modeling and use may be related to the construction of social infrastructure as a requirement for the land auction or an agreement for the development of the territory.

\section{Conclusions}

Thus, author's achievements on modeling of the investment value of land plots for complex residential development demonstrated both their importance and relevance. Scientific and practical recommendations developed based on the author's methodology allows to perform modeling of the optimum investment value of land plots for complex residential development based on the procedure of adjustment of variables of the investment value in terms of the number of floors, participation share of the state and municipal budget in the expenses for socal real estate objects and their minimization.

The work provides practical recommendations on optimum parameters of the publicprivate partnership based on the multivariate graphic and analytical modeling of the cost breakdown structure of the development and consolidated budget when managing the investment value of land plots for complex residential development. Thus, in case of the optimum option of the public-private partnership financing of the construction and engineering social infrastructure creation the state finances $6.3 \%$ and the investor finances $93.7 \%$ (i.e. in the breakeven point, when $\mathrm{NII}=0$ ), the state finances $19 \%$ of the school construction in the amount of RUR $97.26 \mathrm{mln}$.

\section{References}

1. M. Rakovskaya, Moscow Economic Journal 4, 15-20 (2016)

2. An. Mottaeva, V. Lukinov, As. Mottaeva, Economy and entrepreneurship 8(49), 34-37 (2014) 
3. M. Rakovskaya, K. Kulakov, S. Baronin, T. Uchinin, Success of Modern Science 2(9), 122-126 (2016)

4. T. Uchinina, S. Baronin, Izvestiya of the South-Western State University 5-2(38), 325331 (2011)

5. S. Baronin, K.Kulakov, Journal of Advanced Research in Law and Economics 6(2), 291-298 (2015)

6. S. Baronin, K. Kulakov, Journal of Applied Economic Sciences 11(4), 698-708 (2016)

7. S. Baronin, Real estate 1, 58-62 (2009)

8. M. Kamenetsky, Forecasting problems 3, 76-91 (2013)

9. K. Kulakov, E. Denisova, Scientific Review N1, 314-318 (2013)

10. An. Mottaeva, Online magazine of science 6(19), 69 (2013)

11. M. Kumaraswamy, Appropriate appraisal and apportionment of megaproject risks. Journal of Professional Issues in Engineering. Education and Practice 123(2), 51-56 (1997)

12. A. Altshuler, D. Luberoff, Mega-Projects: The Changing Politics of Urban Public Investmen (Brookings. Institution Press, Washington, DC, 2003)

13. An. Mottaeva, As. Mottaeva, Economy and entrepreneurship 3-2(56-2), 98-102 (2015)

14. A. Teshome, J. de Graaff, A. Kessler, Land Use Policy 57, 215-228 (2016)

15. I. Kardes, A. Ozturk, S. Cavusgi, E.Cavusgil, Managing global megaprojects: Complexity and risk management, International (2015)

16. As. Mottaeva, D. Knyazev, Economy and entrepreneurship 10, 626 (2016) 